\title{
TĖVŲ PATIRTYS, UŽTIKRINANT VAIKAMS SAUGIĄ NAMŲ APLINKĄ
}

\author{
Alina Vaškelyte் $\dot{\mathbf{1}}^{1,2}$, Jolanta Navasaityte் $\dot{\mathbf{e}}^{1,2}$ \\ ${ }^{1}$ Kauno kolegijos Medicinos fakulteto Slaugos katedra, \\ ${ }^{2}$ Lietuvos sveikatos mokslu universiteto Slaugos fakulteto Slaugos klinika
}

Raktažodžiai: vaikų traumos, saugi aplinka vaikams, tèvų patirtis.

\begin{abstract}
Santrauka
Traumos yra pagrindinè vaikų mirties ir negalios priežastis visame pasaulyje. Kasmet Europoje nuo netyčinių sužalojimų miršta beveik 42 tūkstančiai vaikų ir paauglių iki 19 metų. Ikimokyklinio amžiaus vaikai daugiausia sužalojimų patiria namuose, o nemažai nelaimingų įvykių galima nuspèti ir išvengti, pasitelkus įvairias priemones, kurių viena - saugios namų aplinkos kūrimas.

Tyrimo tikslas - išanalizuoti tèvų patirtį, susijusią su saugios namų aplinkos užtikrinimu savo vaikams. Atliktas kokybinis tyrimas, kuriame dalyvavo dvylika mamų, auginančių ikimokyklinio amžiaus vaikus. Atliekant tyrimą, taikyti pusiau struktūruoto interviu ir namų aplinkos stebejjimo metodai. Tyrimas buvo vykdomas nuotoliniu būdu, naudojantis išmaniosiomis technologijomis, atliekant ịprastinius ir vaizdo skambučius.

Tyrimo radiniai atskleide, kad kiekvienuose namuose buvo gausybė grèsmę keliančių daiktų: buitinès chemijos priemonių, karštų skysčių ir paviršių, stalčių ir spintelių, aštrių, smulkių daiktų, vaistų. Tyrimo dalyvès pripažino, kad ne kartą yra pastebėjusios vaikų susidomėjimą šiais daiktais. Pastebèta, kad ne tik namų vidaus aplinkoje, bet ir lauke buvo gausu pavojų, tokių kaip: neaptverti keliai, vandens telkiniai, netvarkingos viešosios žaidimų aikštelès. Siekiant išvengti susižeidimų, tèvams teko keisti daiktų laikymo vietas, naudoti specialias apsaugas, užtikrinti nuolatinę vaikų priežiūrą, mokyti vaikus saugaus elgesio pagrindų. Nors tèvai stengiasi namuose sukurti kuo saugesnę aplinką savo vaikams, tačiau nelaimingų atsitikimų išvengti nepavyksta. Vaikai yra patyrę įvairių traumų: kritimo, nudegimo, springimo, įsipjovimo ir kitų nesudètingų susižeidimų. İvykus šiems nelaimingiems atsitikimams,
\end{abstract}

mamos dažniausiai nemokèjo teikti pirmosios pagalbos, jautè pirmosios pagalbos žinių trūkumą. Šios situacijos joms sukeldavo daugybę neigiamų emocijų.

\section{Ivadas}

Traumos ir nelaimingi atsitikimai yra viena pagrindinių sveikatos problemų pasaulyje, o vaikų grupejje tai pagrindinė sergamumo ir mirtingumo priežastis [1-3]. Daugelyje pasaulio šalių ši problema sukelia didžiulę ekonominę naštą ir rimtų emocinių problemų vaikams, jų tẻvams ir visuomenei $[4,5]$. Netyčiniai sužalojimai yra svarbiausios $1-5$ metų vaikų sergamumo ir mirtingumo priežastys, sukeliančios 750000 mirčiu ir 400 milijonų sunkių sužalojimų per metus visame pasaulyje [6]. Lietuvos higienos instituto (HI) duomenimis (2019), Lietuvoje užregistruoti 79533 ambulatoriniai vaikų apsilankymai gydymo ịstaigose dèl netyčinių sužalojimų, iš jų 6360 atvejais prireikè stacionarinio gydymo [7]. Pagrindinè vaikų traumų priežastis, dèl kurios jie buvo gydomi stacionare - kritimai [8]. Didžioji dalis kritimų ịvyko lygioje vietoje ( 54,8 proc.), o kritimą iš aukščio patyrè 20 proc. susižalojusių vaikų. Pagal PSO (2008) strategijas, viena iš priemonių, galinčių padèti išvengti vaikų kritimo - įvairiapusių bendruomeninių programų igyvendinimas, tokių kaip „Vaikai nemoka skraidyti“. Svarbu vaikams pritaikytas kambario baldų ir kitų daiktų dizainas, žaidimų aikštelių standartai: tinkami paviršiai, irangos aukštis ir atitinkama vaikų priežiūra [9].

Lietuvos HI duomenimis (2017), viena dažniausiai patiriamų traumų yra nudegimai ir nuplikinimai, būdingiausi 0-4 metų vaikams [10]. Dažniausiai šios amžiaus grupès vaikai nukenčia dèl nudegimo karštu maistu, gèrimais, riebalais ir maistiniais aliejais, apsipylę karštu vandeniu ar nusiplikę karštais garais. Vaikai dažnai patiria nudegimus, prisiliesdami prie įkaitusio lygintuvo, viryklès, orkaitės ar sumuštinių gaminimo aparatų [11]. Lietuvoje (2015) vykdant ikimokyklinio amžiaus vaikų sužalojimų namuose paplitimo ir priežasčių tyrimą nustatyta, kad nudegimus vaikai daž- 
niausiai patyrè virtuveje ( 68,9 proc.) [12]. Tyrimo rezultatai parodé, kad net 95,8 proc. vaikų nudegimų nutiko prižiūrint suaugusiesiems. PSO (2008) teigè, kad pagrindinès ir efektyviausios priemonès, galinčios padèti išvengti vaikų nudegimo ir nusiplikymo, yra įstatymų dèl dūmų detektorių prièmimas ir jų vykdymas, žiebtuvèlių su apsauga nuo vaikų naudojimas, įstatymų dèl karšto geriamojo vandens priemimas ir vykdymas bei visuomenès švietimas [9].

PSO duomenimis (2017), skendimas yra viena iš labiausiai nepastebètų išvengiamos mirties priežasčių visame pasaulyje [13]. Irane (2020) buvo atliktas tyrimas, išaiškinęs motinų požiūrị ị vaikų traumų prevenciją [14]. Tyrimo rezultatai parodè, kad namuose tèvai labiausiai rūpinasi apsinuodijimo prevencija, nemažai demesio skiria ịsipjovimo ir kritimo prevencijai, o mažiausiai dèmesio kreipia ị skendimo prevenciją ir eismo saugumą. PSO (2014) pristate skendimo prevencijos strategiją mažinti skendimo rodiklius: riboti vaikų priëjimą prie vandens telkinių, intensyvinti priežiūrą, baseinus aptverti apsauginèmis tvorelèmis, šulinius uždengti specialiais dangčiais, mokyti vaikus plaukti [15].

Aspiracija dèl svetimkūnio rijimo yra viena iš pagrindinių jaunesnių nei ketverių metų vaikų traumų, hospitalizavimo ir mirties priežasčių [16]. Nors dauguma mirčių dèl springimo ịvyksta pirmaisiais gyvenimo metais, tačiau padidejusi hospitalizavimo rizika išlieka iki šešerių metų. Mygtukai, plastikiniai užsukamieji kamšteliai, dangteliai, monetos, diskinès baterijos, lateksiniai balionai, smulkūs žaislai, rutuliukai, maži guminiai kamuoliukai, maisto produktai, nuo pakuočių nuplèšti plastikiniai kampai - tai pavojingiausi daiktai, kurie dažniausiai sukelia vaikų aspiraciją [16]. Siekiant sumažinti vaikų springimo riziką, būtina laikytis amžiaus rekomendacijų, nurodytų ant žaislų pakuotès, vengti magnetinių žaislų naudojimo, ịsitikinti, ar žaisluose tinkamai ir saugiai sudetos baterijos, patikrinti, ar jos neprieinamos vaikui. Svarbu įsitikinti, kad stambių žaislų smulkios detalès yra tinkamai pritvirtintos. Siekiant sumažinti vaiku apsinuodijimo medikamentais skaičių, rekomenduojama naudoti saugias medikamentų pakuotes, mažos talpos buteliukus, laikyti mažą tablečių kiekị lapelyje ar buteliuke, naudoti apsauginius vaistinėlès užraktus, drausti vaikams savarankiškai, nesant tėvų ar kitų suaugusiųjų priežiūros, gerti vaistus ar vitaminus [17,18].

Beprasmès mirtys, neigalumas, dideli socialiniai ir ekonominiai nuostoliai skatina suaktyvinti susižalojimų prevencinę veiklą [19]. Skandinavijos šalių, Nyderlandų patirtis ir kelis kartus mažesni vaikų mirtingumo dẻl sužalojimo rodikliai rodo, kad traumos yra išvengiamos ir tai galima kontroliuoti. Tam tikslui būtina sukurti efektyvias, kryptingas ir ilgalaikes prevencines programas bei jas igyvendinti [20].

Tyrimo tikslas - atskleisti tėvų patirtis, užtikrinant vaikams saugią namų aplinką.

\section{Tyrimo medžiaga ir metodai}

Atliktas kokybinis tyrimas. Duomenys rinkti pusiau struktūruoto interviu metodu, kuris leido ịsigilinti ị tèvų patirti, jausmus ir išgyvenimus. Vykdytas namų aplinkos

1 lentelè. Tyrimo dalyvių charakteristikos.

\begin{tabular}{|c|c|c|c|c|c|c|}
\hline $\begin{array}{l}\text { Tyrimo } \\
\text { dalyvẻ }\end{array}$ & $\begin{array}{l}\text { Amžius } \\
\text { (metai) }\end{array}$ & $\begin{array}{c}\text { Šeimyninè } \\
\text { padètis }\end{array}$ & $\begin{array}{c}\text { Vaiku } \\
\text { skaičius }\end{array}$ & Išsilavinimas & $\begin{array}{c}\text { Gyvenamoji } \\
\text { vieta }\end{array}$ & $\begin{array}{l}\text { Gyvenamasis } \\
\text { būstas }\end{array}$ \\
\hline Laima & 34 & Ištekèjusi & 2 & Aukštasis universitetinis & Miestas & Butas \\
\hline Rasa & 31 & Ištekèjusi & 2 & Aukštasis universitetinis & Kaimas & Namas \\
\hline Gabrielè & 38 & Ištekèjusi & 3 & Aukštasis universitetinis & Miestas & Namas \\
\hline Aušrinè & 37 & Ištekèjusi & 1 & Aukštasis universitetinis & Kaimas & Namas \\
\hline Paulina & 32 & Ištekèjusi & 2 & Aukštasis universitetinis & Miestas & Butas \\
\hline Sigita & 26 & Ištekèjusi & 2 & Profesinis & Kaimas & Namas \\
\hline Monika & 29 & Ištekèjusi & 2 & $\begin{array}{c}\text { Aukštasis } \\
\text { neuniversitetinis }\end{array}$ & Kaimas & Namas \\
\hline Laura & 29 & Ištekèjusi & 2 & $\begin{array}{c}\text { Aukštasis } \\
\text { neuniversitetinis }\end{array}$ & Kaimas & Namas \\
\hline Jurgita & 29 & Ištekèjusi & 2 & $\begin{array}{c}\text { Aukštasis } \\
\text { neuniversitetinis }\end{array}$ & Miestas & Butas \\
\hline Rugilè & 39 & Netekèjusi & 1 & Aukštasis universitetinis & Miestas & Butas \\
\hline Patricija & 35 & Ištekèjusi & 2 & Aukštasis universitetinis & Kaimas & Namas \\
\hline Karina & 38 & Ištekèjusi & 2 & Aukštasis universitetinis & Miestas & Butas \\
\hline
\end{tabular}


stebejjimas, kurio metu buvo galima pamatyti ir įsitikinti, kaip vaikams užtikrinamas saugumas, kokios namuose naudojamos prevencinès priemonès. Dèl šalyje paskelbto karantino ir jo apribojimų, tyrimas buvo vykdomas nuotoliniu būdu, naudojantis išmaniosiomis technologijomis, atliekant garso ir vaizdo skambučius. Tiriamujų imtis suformuota tikslinès atrankos būdu, taikant „sniego gniūžtès“ metodą.

Tyrime, kuris vyko 2020 m., dalyvavo 12 moterų, auginančių ikimokyklinio amžiaus vaikus. Dauguma tyrimo dalyvių buvo ištekejjusios, turinčios aukštaji išsimokslinimą. Tyrimo dalyvių amžius svyravo nuo 26 iki 39 metų. Tiriamosiose šeimose augo 1-3 ikimokyklinio amžiaus vaikai. Išsamesnès informančių charakteristikos pateikiamos 1 lentelèje. Gavus tyrimo dalyvių sutikimus, interviu buvo įrašyti ị diktofoną, vèliau paversti tekstu. Gautieji duomenys analizuoti taikant indukcinę turinio analizę. Išskiriami reikšminiai kodai, kurie buvo sujungiami ị potemes, o panašios potemès sujungtos ị temas. Ilgiausio interviu trukmé buvo $49 \mathrm{~min}$., trumpiausio - 23 min., bendra interviu trukmè: 7 val. 15 minučių.

Tyrimo metu buvo užtikrintas informančių anonimiškumas ir konfidencialumas: visa asmeninè informacija buvo užšifruota, pakeičiant identifikuoti galinčias detales, vietovardžius, pavadinimus, vardus, pavardes. Tyrimui atlikti gautas LSMU Bioetikos centro leidimas Nr. BEC - ISP(M) - 82.

\section{Tyrimo rezultatai ir diskusija}

Atlikus interviu ir namų aplinkos stebejjimo duomenų analizę, buvo suformuluotos penkios pagrindinès temos: „Sudètingas namų aplinkos kūrimas“, „Tykantys pavojai lauke“, „Nuolatinis vaiko mokymas“, „Tèvai irgi mokosi“, „Skaudi traumų patirtis“. Kiekviena išryškejusi tema atskleidžiama per jai priskirtas potemes. Temų ir potemių žemèlapis pateiktas 1 paveiksle.

Sudėtingas namų aplinkos kūrimas. Kalbantis su mamomis ir stebint jų namų aplinką atsiskleide, kad kiekvienuose namuose yra gausybė grèsmę keliančių daiktų: buitinès chemijos priemonių, karštų skysčių ir paviršių, stalčiu ir spintelių, aštrių, smulkių daiktų, vaistų. Moterys pripažino, kad ne kartą yra pastebejjusios vaikų susidomėjimą šiais daiktais, todèl tèvams dažnai tenka keisti jų laikymo vietas, naudoti specialius užraktus, įsigyti išmaniuosius ịrenginius, kurie užtikrintų apsaugą nuo vaikų: ,, Viryklę mes specialiai pirkome tokia, kuria prilietus - pirštu nenusideginsi. Ji neįkaista “" (Patricija). Mamos atviravo, kad daugiausiai demesio kreipia į verdančiu vandeniu užpilamus gèrimus - kavą, arbatą ar vaikui ruošiamą kakavą. Beveik visos moterys dalinosi patirtimi, kad karštų skysčių niekada nepatiekia vaikams. Dažniausiai kaip saugiausią vietą karštiems skysčiams vėsti, tèvai renkasi aukštesnę spintelę ar virtuvès stalviršị. Tik ịsi-

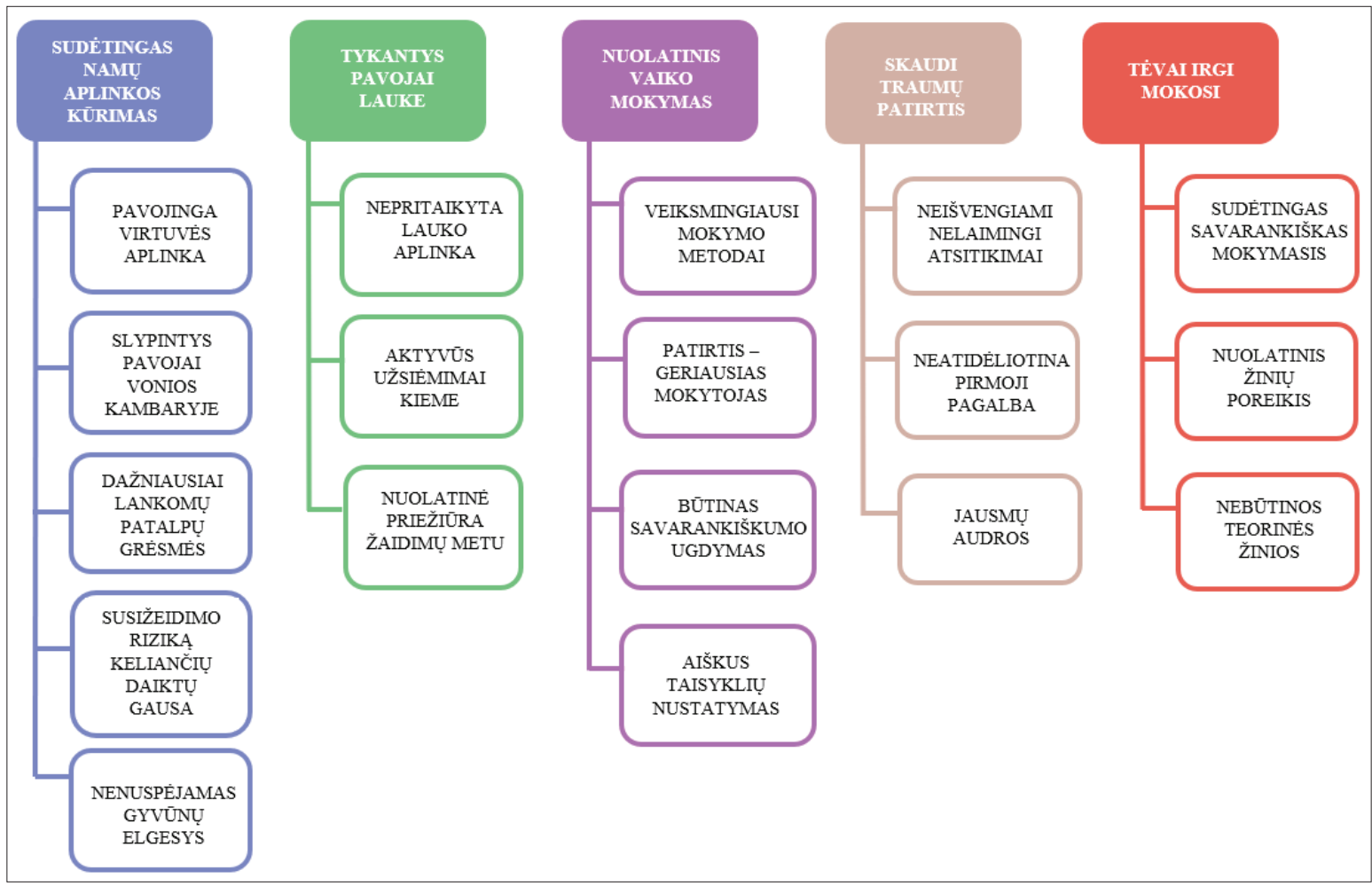

1 pav. Temų ir potemių žemèlapis 
tikinus, kad skysčiai yra tinkamos temperatūros, jie paduodami vaikams: ,, <..> ant stalo jie nestovi iki tol, kol kažkiek bent jau kol vidutiniškai nepravèsta, o toliau jau leidžiamès tikrintis pagal save védinamès, pučiamès kartu" (Kamilè). Dauguma mūsų tyrimo dalyvių išreiškè didelį susirūpinimą dèl namuose laikomų vaistų. Moterys nerimavo, kad vaikai nepaimtų ir neparagautų pavojingų medikamentų, todèl vaistus dažniausiai namuose laiko vaikams nematomoje ir nepasiekiamoje vietoje: ,,Vaistai namuose yra vienoje vietoje, sukelti aukštai, mūsu miegamajame, aukštai spintoje - ten, kur vaikai lengvai nepasiekty" (Patricija).

Lietuvoje (2015) buvo atliktas tyrimas kurio metu nustatyta, kad daiktų laikymas vaikams nepasiekiamoje vietoje ir pakankamas tèvų (globejų) informuotumas vaiko saugos namuose klausimais yra apsauginiai veiksniai, mažinantys sužalojimų namuose riziką [12]. Vykdant mūsų tyrimą, namų aplinkos stebejjimo metu buvo pastebèta, kad keliuose namuose vaistai neturi vienos tvarkingos, pastovios laikymo vietos, o vaikai turi galimybę patys pasiimti vaistus ir juos išgerti. Pastebèta, kad tèvai dažnai pervertina savo žinias ir yra labai pasitikintys savimi. Tai patvirtina ir D. Gružienès (2018) magistrantūros baigiamojo darbo rezultatai, kuriame buvo nustatyta, kad 70,5 proc. tèvų nurodé, jog namuose užtikrino saugią aplinką vaikui, dar 29,5 proc. teigè, kad užtikrino iš dalies, tačiau priešgaisrinė apsauga buvo ịrengta tik 33 proc. namų ūkių [21].

Mūsų tyrimo dalyvès, kalbėdamos apie namuose esančius pavojus, prakalbo apie naminius gyvūnus. Mamos atviravo, kad jie tampa geriausiais vaikų draugais, jiems suteikia daug džiaugsmo, tačiau baiminasi, kad nenuspejamai besielgiantys gyvūnai gali sužeisti jų vaikus: ,, $<$..> atrodo lyg ir viskas gerai, draugiški jie, bet... Nežinai kada gali ar susukti, ar ikasti “ (Rasa). Namų aplinkos stebèjimų metu pastebèta, kad dažniausiai katės ir šunys namuose auginami laisvai, vaikai bet kuriuo metu gali žaisti su savo augintiniu, o suaugusiųjų priežiūra yra nebūtina. Tik vienuose namuose dèl vaikų saugumo katei buvo karpomi nagai.

Tykantys pavojai lauke. 7 tyrimo dalyvès gyveno nuosavuose namuose ir 5 butuose. Puse informančiu gyveno mieste ir pusè kaimo vietovèse, todèl prakalbus apie vaiko užsiemmimus lauke moteru patirtis išsiskyrè. Lietuvos HI duomenų ataskaitoje (2012) vaikų patirtų traumų dažnumas skiriasi susižalojimų priežasčių struktūra pagal gyvenamają vietą: kaimo vaikai rečiau susižalojo, nei miesto [10]. Visos mūsų tyrimo dalyvès pripažino, kad lauke taip pat gausu pavojų: neaptvertų kelių, vandens telkinių, netvarkingų viešujų žaidimų aikštelių: „,Niekur niekas neaptverta: nei prūdas, nei kiemas, nei kelias, niekas neaptverta " (Aušrinè). Šeimos, gyvenančios butuose, nurodè privataus kiemo trūkumą. Tyrimo dalyvès pastebėjo, kad ne viena žaidimų aikštelè netinkama vaikų užsièmimams. Dažnai jose būna sugadintas inventorius, nesaugi danga, netinkama aplinka, didinanti susižeidimo riziką, todèl dauguma tèvų stengiasi vengti tokiu vietų: ,, < ..> mes pasirenkame saugias aikšteles, kad nebūtu betono gabalu, kaip būna, ar šaku, ar stiklu, žiūrime, pasirenkame saugia, kad tvarkinga bütü" (Karina).

Jungtinejje Karalystejje (2019) per metus vaikų žaidimų aikštelèse įvyksta apie 40000 nelaimingų atsitikimų, kurių metu vaikams prireikia mediku pagalbos. Beveik 40 proc. susižeidimų nutinka dèl žaidimų aikštelèse esančios įrangos [19]. Lietuvoje (2018) atlikto tyrimo metu nustatyta, kad vaikų kritimas nuo žaidimų aikštelių įrenginių sudarẻ 12,6 proc. nuo tyrime dalyvavusių vaikų skaičiaus [21]. Beveik visos mūsų tyrimo dalyvès buvo įsitikinusios, kad vaikams lauke saugiausia, kai jie prižiūrimi suaugusiųjų, todèl dauguma teige, jog stengiasi niekuomet nepalikti vaiku be priežiūros: ,, <..> mano pasirinkimas, kad jau reikia ji akylai saugoti ir aš nei jo palikdavau, nu beveik net nenusisukdavau" (Aušrinè). Moterys tvirtino, kad jeigu jos ar ju vyrai negali prižiūrèti kieme žaidžiančių vaikų, prašo pagalbos savo artimųjų: senelių, draugų, kaimynų ar kitų šeimos narių. Jungtinèse Amerikos Valstijose (JAV) atlikto tyrimo (2012) duomenimis, tikimybė, kad vaikas patirs sužalojimą prižiūrimas vyresnių nei 54 metų asmenų, yra mažesnè, nei prižiūrimas asmenų iki 35 metų [22]. Nustatyta, kad vaikams, prižiūrimiems nuo depresijos kenčiančių asmenų, susižalojimo tikimybè dideja, todèl suaugusiojo priežiūra ne visada garantuoja, jog vaikas yra tinkamai prižiūrimas ir nepatirs sužalojimų. Tam ịtakos gali turèti prižiūrinčiujų išsiblaškymas, sveikatos būkle ar atidumo stoka [23]. Irane (2016) atliktas tyrimas įrodè, kad motinų, turinčių mažiausiai 3 vaikus, saugumo elgesys prastesnis [6]. Šis dèmesio prevencinèms sužalojimų priemonèms sumažèjimas gali būti siejamas su trumpesniu laiku, skiriamu vaikų priežiūrai [6].

Nuolatinis vaiko mokymas. Tyrimo dalyvès buvo ịsitikusios, kad norint užtikrinti mažylių saugumą, nepakanka saugios namų aplinkos - vaikus būtina mokyti. Kanadoje (2014) atlikto tyrimo rezultatai patvirtino, kad tèvai deda daug pastangų, mokydami vaikus saugumo. Tévai ịsitikinę, kad mokymas yra tinkama vaiko rizikingo elgesio valdymo strategija [24].

Mūsų tyrime atsiskleidè, kad kiekviena šeima pasirenka jiems priimtiniausią ir tinkamiausią mokymo metodą. Vieni pasikliauja žodiniu mokymu, kitiems tai atrodo nepakankama, todèl pasitelkia papildomas priemones. Tyrimo dalyvès atskleidé, kad dažnai ị pagalbą pasitelkè internete arba televizijoje randamą vaizdo medžiagą: mokomuosius filmukus, reklamas. Mamos tvirtino, kad tokia medžiaga daug efektyvesnè: vaikai lengviau įsiminè informaciją ir dažnai ją prisimindavo: „,Parodome pavyzdžius, ieškome vaizdeliu 
internete, kad gali büti <..> pasakojama kaip prispaudžia vaikus, kaip jie neišgyvena " (Rasa). Kitos šeimos įsitikinusios, kad efektyviausias mokymas yra vaiko patirtis. Jos tvirtino, kad tik ịgiję asmeninès patirties, vaikai gali suvokti situacijos pavojingumą, ịvertinti savo veiksmų pasekmes: , <...> teorija ir žodinis mokymas be praktikos, tai tas pats, kad išvis beveik nieko. Kad žinos, bet nebus pajutęs, kaip ten skauda ta piršta prisispaudus ar ten kitaip kažkaip užsigavus - tai nebus vaikui joks situacijos ir pavojaus supratimas, vertinimas " (Kamile). Tai įrodo JAV (2012) atliktas tyrimas, kurio metu nustatyta, kad vaikai natūraliai susidurdami su susižeidimų rizika lavina suvokimo ir pažinimo gebẻjimus adekvačiai ịvertinti rizikingas situacijas. Per daug apribojus vaikų rizikingus žaidimus lauke - lètejja raida [25].

Mūsų tyrimo dalyvès teigè, kad būtina vaikus mokyti saugaus elgesio taisyklių, savarankiškumo pagrindų, nustatyti griežtas ir aiškias namų taisykles. Lietuvoje (2015) atliktame tyrime teigiama, kad netinkami mokymo būdai, tokie kaip ịvairūs draudimai, nurodymai - nesulaiko vaikų nuo neatsargaus elgesio [12]. Pasak Lietuvos edukologijos srities atstovų ir psichologų (2016), vaikų ugdymas turètų būti orientuotas ì vaiko raidai reikalingų sąlygų sudarymą [26].

Skaudi traumų patirtis. Nors tèvai stengiasi namuose sukurti kuo saugesnę aplinką savo vaikams, užtikrinti tinkamą priežiūrą, tačiau mamos įsitikinusios - nelaimingi atsitikimai neišvengiami. Tokios pat nuomonès buvo ir Azerbaidžane (2020) atlikto tyrimo dalyvès, ịsitikinusios, kad nepilnamečių vaikų susižeidimas namų aplinkoje yra normalus reiškinys, nors 85,1 proc. tyrimo dalyvių tikino, kad šių traumų buvo galima išvengti [14]. Mūsų tyrimo dalyvès taip pat pripažino, kad beveik visada galvodavo apie ìvykusių traumų priežastis, svarstydavo, kaip buvo galima išvengti susižeidimo. Jos galvojo, kad reikejjo atsakingiau ivertinti aplinką, naudoti specialias apsaugos priemones, užrakinti pavojingas namų vietas ir daiktus, atsakingiau palaikyti tinkamą tvarką namuose ir atidžiau prižiūrèti savo vaikus: „, Galvojau, kad reikejo gražiai, ramiai, nepasitikint juo pabudèti šalia, kol jis nuneštu, ìdètu (praryta moneta) ir tada pasitraukti daryti savo reikalu" (Rugile)).

Mūsų tyrimo dalyvių vaikai dažniausiai patyrẻ kritimą, springimą, nudegimą, susižeidimą aštriais įrankiais ir kitas nedideles traumas. Tokia tendencija buvo pastebèta Lietuvoje (2018) atlikto tyrimo metu, kuriame nustatyta, kad dažniausia vaikų traumų priežastis buvo kritimas $-66,9$ proc. ir nudegimas $-9,6$ procento [21]. Panašią situaciją nustatė $\mathrm{L}$. Šauklytė (2014) magistrantūros baigiamajame darbe: apsinuodijimas, nusideginimas, įsipjovimas - pagrindiniai vaiku nelaimingi atsitikimai namuose [27]. Lietuvos HI duomenimis (2018), dažniausia vaikų traumų priežastis - kritimas [8]. Irane (2017) buvo atliktas tyrimas ir išanalizuoti dažniausiai patiriamų traumų mechanizmai. Nustatyta, kad nudegimas, kritimas ir apsinuodijimas yra labiausiai paplitusios ikimokyklinio amžiaus vaikų traumos [28].

Mūsų tyrimo dalyvès atviravo, kad vaikus namuose dažniausiai domino pavojinga veikla: šokinejjimas ar lipimas ant namuose esančių baldų, daiktų: lovų, spintelių, laiptų, lentynų, skalbyklių. Tai pagrindinès priežastys, dèl kurių vaikai patyrè kritimą: ,, Jis tiek šokinejo, kad jis su galva i siena trenkèsi ir pas ji guzas buvo galvoj... "(Laima). Šiu skaudžių traumų metu vaikai patirdavo kirstinių galvos žaizdų, rankų, kojų, galvos stiprių sumušimų ar net galūnių lūžių. Dauguma moterų pripažino, kad ištikus kritinei situacijai, jos nežinojo kaip teisingai suteikti pirmają pagalbą. Tyrimo dalyvès baiminosi, kad šis žinių trūkumas gali nulemti nelaimingo atsitikimo tragišką baigtị: , ,Ir jeigu tai tikrai tai pasibaigtu mirtimi, tada aš save užsigraužčiau tiek, kad čia mano vaikas, o aš jam negalejau suteikti pagalbos. Galvočiau, kad tai nutiko per mane" (Rugilè).

Ukrainoje (2015) atlikto tyrimo rezultatai parode, kad žinių apie traumų prevenciją ir pirmają pagalbą trūksta ne tik tèvams, bet ir sveikatos priežiūros specialistams [29].

Mūsų tyrimo dalyvès, kalbėdamos apie vaikų patirtus nelaimingus atsitikimus, išsakè daug skirtingų emocijų ir jausmų. Ne viena mama pripažino, kad ị vaikų patiriamas traumas reagavo itin jautriai. Jos nerimavo dèl vaiko patirto skausmo, emocijų ir galimų traumos pasekmių: „, Aš labai jautriai reaguoju ị šitus dalykus. Man kažkoks... Jau man kažkoks košmaras, o jetau, aš greitai prisigalvoju, o jeigu smegenu sutrenkimas, mažas vaikas ir visa kita! " (Aušriné). Dažniausiai vaikų traumos tèvams sukeldavo jaudulị, išgąstị, baimę, stresą, kaltès ir beviltiškumo jausmus.

Tévai irgi mokosi. Tyrimo dalyvès tikino, kad vaiko auginimas - sudètingas procesas ir šiuo laikotarpiu tenka mokytis ne tik vaikams, bet ir jų tėvams. Kai kurios moterys neslëpè, kad ypač pirmojo vaiko auginimas sukèlẻ daug sunkumų: ,, < ..> aš nemokejjau auginti pirmo vaiko, nes man pirmiausiai reikëjo susivokti, kad aš esu atsakinga už šita vaika "(Monika). Beveik visos tyrimo dalyvès pripažino jautusios žinių ir ịgūdžių trūkumą, o ypač pasigedo sveikatos priežiūros specialistų dẻmesio ir jų teikiamos informacijos. Mūsų tyrimo dalyvès prisiminè, kad dažnai medicinos personalo vizitai i namus ir teikiamos konsultacijos buvo tik oficialumas: ,, <..> pirmu tu vizitu metu tai tik formalumas sakyčiau ten buvo: padare ten $\mathrm{ka}$, užsidejo ten ta vadinama pliusa, ị sistema ịraše “ (Gabrielè). Moterys teigè, kad sveikatos priežiūros specialistų pagalba ir teikiama informacija būtų buvusi labai reikalinga. Joms norejosi, kad šeimos gydytojai, slaugytojai, būtų rūpestingesni: domètųsi vaiko augimu, teiktų naudingą informaciją tèvams. Dauguma moterų pripažino, kad žinių ir ịūdžių išmoko per patirtí, 
išgirdo iš draugų, pažistamų ar šeimos: ,, <..> kad kažkokie specialistai man patartu tai ne, viskas ateina kažkaip savaime: per draugus, per patirtị" (Monika). Mūsų tyrimo dalyvès išreiškè norą gauti daugiau informacijos traumu prevencijos tema ir pateike rekomendacijas sklaidai gerinti. Moterys rekomendavo priemones, kurios joms būtų aktualios: skrajučių platinimą, informacijos skelbimą socialiniuose tinkluose, mokymu organizavimą: ,, Tikrai galètu gal koki padaryti lankstinuka, aprašyti kažka, duodi atmintinę kažkokia $<\ldots>$ ". (Justina).

Irane (2020) atlikto tyrimo rezultatai parode, kad masinès žiniasklaidos priemonès tokios kaip televizija, radijas ir socialiniai tinklai galètų padidinti motinų žinias, keisti požiūrị ir ugdyti vaikų saugumą namuose [14]. Mūsų tyrimas atskleidè, kad moterys nori mokymų, kuriuose būtų teikiama ne tik teorinè informacija, bet rodoma ir vaizdinè medžiaga. Gerokai anksčiau Irane (2012) atliko tyrimo rezultatai parodè, kad pagrindiné priemoné, lèmusi geresnị tėvų suvoktą jautrumą ir suvoktą problemos rimtumą, buvo sužeistų vaikų nuotraukos [30]. Mūsų tyrimo dalyvès siūlè organizuoti vizitus ị namus, kurių metu būtų ịvertinama aplinka ir teikiamos rekomendacijos apie galimus ir reikiamus pokyčius. PSO (2008) ataskaitoje apie vaikų sužalojimų prevenciją pastebèta, kad specialistų lankymosi namuose programos prisidèjo prie namų aplinkos kokybès gerejjimo. Tai efektyvi priemonè mažinti vaikų netyčinio susižeidimo rodiklius [9].

\section{Išvados}

1. Kiekvienuose namuose buvo grèsmę keliančių daiktų, lengvai prieinamų vaikams. Lauko aplinkoje tèvai susidūrẻ su neaptvertų kelių, vandens telkinių pavojais ir netvarkingomis viešosiomis žaidimų vietomis. Siekdami užtikrinti kuo saugesnę aplinką vaikams, tėvai ėmėsi ịvairių prevencinių priemonių: naudojo specialias apsaugas, užraktus, įsigijo išmaniuosius įrenginius, keitė savo ịpročius, stengèsi nuolat prižiūrèti vaikus.

2. Tẻvai nuolatos mokè vaikus saugaus elgesio pagrindų. Šeimos pasirinko jiems tinkamiausią mokymo metodą: aiškių taisyklių taikymą, žodinị mokymą, pavyzdžio rodymą, vaizdo medžiagą. Daugelis tèvų leido vaikams mokytis iš patirties, kad vaikai patys galètų ịvertinti situacijos pavojingumą ir žinotų savo veiksmų pasekmes. Vaikų auginimo metu mamoms teko ne tik ugdyti vaikus, bet ir mokytis pačioms. Moterims pritrūko sveikatos priežiūros specialistų dèmesio, rekomendacijų, patarimų traumų prevencijos tema. Daugiausia žinių jos ịgijo iš asmeninès patirties ir iš kitu tèvų, auginančių panašaus amžiaus vaikus.

3. Moterys jaute pirmosios pagalbos žinių trūkumą ir, ìvykus nelaimingiems atsitikimams, nemokejjo teikti pirmosios pagalbos. Pirmosios pagalbos veiksmų mamos ieškojo internete arba skubiai vyko ị gydymo ịstaigą. Vaikų traumos tèvams sukèlè daugybę neigiamų emocijų.

\section{Literatūra}

1. European report on child injury prevention. http://www.euro. who.int/_data/assets/pdf_file/0003/83757/E92049.pdf?ua=1 .

2. Afshari M, Moghimbeigi A, Rezapur-Shahkolai F. Effect of a model-based educational program for mothers, on home-related injury prevention among under-five-year children in rural Twiserkan, Iran. Turk J Pediatr 2017;59(6):648-656. https://doi.org/10.24953/turkjped.2017.06.005

3. Jociutė A., Zolubienė E., Avelytė J., Izokaitis M. Vaikų mirtingumo dèl išorinių priežasčių mažinimo planavimas. Vilnius, Higienos institutas, 2019:48. https:/www.hi.lt/uploads/pdf/ leidiniai/Rekomendacijos/Vaiku_mirtingumas_rekomendacijos_vstc.pdf.

4. Sleet DA. The Global Challenge of Child Injury Prevention. International Journal of Environmental Research Public Health 2018;15(9):1-7. https://doi.org/10.3390/ijerph15091921

5. Pediatric injury prevention: Epidemiology, history, and application. https://www.uptodate.com/contents/pediatric-injuryprevention-epidemiology-history-and-application.

6. Younesian S, Mahfoozpour S, Shad EG, Kariman H, Hatamabadi HR. Unintentional Home Injury Prevention in Preschool Children; a Study of Contributing Factors. Emergency (Tehran) 2016;4(2):72-77.

7. Ambulatorinių ligonių, gydytų stacionaro prièmimo-skubios pagalbos skyriuje ir ligonių, gydytų stacionare nuo traumų, skaičius pagal diagnozes. https://stat.hi.lt/default.aspx?report $\mathrm{id}=175$

8. Higienos institutas. Lietuvos vaikų sveikatos būklès pokyčiai ir netolygumai. https://www.hi.lt/uploads/pdf/leidiniai/Informaciniai/Vaiku-sveikatos-leidinys_2020.pdf

9. World report on child injury prevention. https://apps.who.int/ iris/bitstream/handle/10665/43851/9789241563574_eng. pdf? sequence $=1 \&$ is Allowed $=y$

10. Higienos institutas. Visuomenés sveikatos netolygumai: Lietuvos vaikų traumos ir jų priežastys. https:/www.hi.lt/uploads/ pdf/leidiniai/Informaciniai/Vaiku\%20traumos.2017(1).pdf

11. Abeyasundara SL, Rajan V, Lam L, Harvey JG, Holland AJA. The changing pattern of pediatric burns. J Burn Care Res 2011;32(2):178-84.

https://doi.org/10.1097/BCR.0b013e31820aada8

12. Ikimokyklinio amžiaus vaikų sužalojimų namuose paplitimo ir priežasčių tyrimas Lietuvoje. http://www.smlpc.lt/media/ file/SMLPC-informacija/Veikla/Tyrimai-analizes/JR_INSNTataskaita_red.pdf

13. Causes of Death. https://ourworldindata.org/causes-of-death

14. Saadati M, Tabrizi JS, Rezapour R, Kalajahi RA. Home injury prevention attitude and performance: a community-based study in a designated safe community. J Inj Violence Res 2020;12(2):145-152. 
https://doi.org/10.5249/jivr.v12i2.1506

15. Gururaj G. Injury prevention and care: an important public health agenda for health, survival and safety of children. Indian J Pediatr 2013;80(1):S100-S108. https://doi.org/10.1007/s12098-012-0783-z

16. Denny SA, Hodges NL, Smith GA. Choking in the Pediatric Population. American Journal of Lifestyle Medicine 2014; 9(6): 438-441. https://doi.org/10.1177/1559827614554901

17. Frattaroli S, Shields W, Omaki E, Molloy M, Gielen AC. How Are Prescription Medications Stored in Urban Homes Where Children Live? Opportunities for Poisoning Prevention. Clin Pediatr (Phila) 2017; 56(7):678-681. https://doi.org/10.1177/0009922816668631

18. An In-Depth Look at Keeping Young Children Safe Around Medicine. https://www.safekids.org/sites/default/files/2013medication-safety-report.pdf

19. Child Safety Product Guide: potentially dangerous products. Birmingham: European Child Safety Alliance. https:/www.skafor.org/contentassets/ab5fe38f080c409d90b0f60d3279f39b/ europeisk-rapport---child-product-safety-guide.pdf

20. Metodinès rekomendacijos: Mokinių sužalojimų profilaktika. http://www.smlpc.lt/media/file/Skyriu_info/Metodine medziaga/vaiku_sveikata/MOKINIU\%20SÜZALOJIMU\%20 PROFILAKTIKA.pdf

21. Gružienė D. 2 - 5 metų amžiaus vaikų fizinių trauma ypatumų ir saugios aplinkos vertinimas tẻvų požiūriu. Baigiamasis magistro darbas: LSMU, 2018:13-66.

22. Schneiderman JU, Leslie LK, Hurlburt MS, Zhang J, McCue Horwitz S. Caregiver Reports of Serious Injuries in Children Who Remain at Home After a Child Protective Services Investigation. Matern Child Health J 2012;16(2):328-335. https://doi.org/10.1007/s10995-010-0714-4

23. Huynh HT, Demeter NE, Burke RV, Upperman JS. The Role of Adult Perceptions and Supervision Behavior in Preventing Child Injury. J Community Health 2017;42(4):649-655. https://doi.org/10.1007/s10900-016-0300-9

24. Morrongiello BA, McArthur BA, Bell M. Managing children's risk of injury in the home: Does parental teaching about home safety reduce young children's hazard interactions? Accident Analysis and Prevention 2014;71:194-200.

https://doi.org/10.1016/j.aap.2014.04.016

25. Brussoni M, Olsen LL, Pike I, Sleet DA. Risky Play and Children's Safety: Balancing Priorities for Optimal Child Development. Int J Environ Res Public Health 2012;9(9):3134- 3148. https://doi.org/10.3390/ijerph9093134

26. Burvytė S. Tẻvų, auginančių ikimokyklinio amžiaus vaikus, pozityviosios tėvystės suvokimas. Edukacinè tradicija ir inovacijos, 2016;44(3):36-57.

http://socialinisugdymas.leu.lt/index.php/socialinisugdymas/ article/view/179/166

27. Šauklytė L. Ikimokyklinio amžiaus vaikų teisių saugiai aplin- kai užtikrinimas namuose taikant socioedukacines priemones. Baigiamasis magistro darbas: Šiaulių universitetas, 2014:5-65.

28. Nouhjah S, SRN Kalhori, Saki A. Risk factors of Non-fatal Unintentional Home Injuries among Children under 5 Years Old; a Population-Based Study. Emerg (Tehran) 2017;5(1):1-7.

29. Gamelli L, Mykychack I, Kushnir A, Driscoll DN, Fuzaylov G. Targeting burn prevention in Ukraine: evaluation of base knowledge in burn prevention and first aid treatment. J Burn Care Res 2015;36(1):225-231.

https://doi.org/10.1097/BCR.0000000000000103

30. Cheraghi P, Poorolajal J, Hazavehi SMM, Rezapur-Shahkolai F. Effect of educating mothers on injury prevention among children aged $<5$ years using the Health Belief Model: a randomized controlled trial. Public Health 2014;128(9):825-830. https://doi.org/10.1016/j.puhe.2014.06.017

\section{PARENTS ' EXPERIENCES IN ENSURING A SAFE HOME ENVIRONMENT FOR THEIR CHILDREN}

\section{A. Vaškelytė, J. Navasaitytè}

Keywords: childhood injuries, safe home environment, parents' experiences.

Summary

Injuries are the leading cause of death and disability among children worldwide Almost 42.000 children and adolescents under the age of 19 die in Europe from unintentional injuries every year. Preschool children are the main victims of injuries at home, and a number of accidents can be predicted and prevented through a variety of measures, one of which is to create a safe home environment.

A qualitative study involving twelve participants was conducted to analyze parents' experiences of providing a safe home environment for their children. Data were collected using a semistructured interview as well as methods of monitoring participants' house environment. The study was conducted remotely using visual calls and phone calls.

The findings of the study revealed that every home had a plethora of threatening items: household chemicals, hot liquids and surfaces, drawers and cabinets, sharp, small items, medicines. Study participants admitted that they have repeatedly noticed children's interest in these items. It was observed that not only in the indoor environment of the house, but also outdoors, there were many dangers, such as: unfenced roads, ponds, untidy public playgrounds. In order to avoid injuries, parents had to change storage places, use special guards, ensure constant childcare, and teach children the basics of safe behaviour. The findings of the study revealed that although parents try to create the safest possible environment for their children at home, accidents cannot be avoided. Children have suffered a variety of injuries: falls, burns, chokings, cuts, and other minor injuries. When these accidents occurred, mothers were usually unable to provide first aid and felt a lack of first aid training. These situations caused a lot of negative emotions.

Correspondence to: alina.vask@gmail.com

Gauta 2021-09-14 